\title{
TRADISI KELAKAT DALAM PERKAWINAN MASYARAKAT MUSLIM KELURAHAN LOLOAN TIMUR KABUPATEN JEMBRANA BALI
}

\author{
Usriah \\ Fakultas Syariah UIN Maliki \\ Telp. 081353309021 \\ Email: us_ria@yahoo.com
}

\begin{abstract}
Abstrak
Suatu kepercayaan pada sebagian orang tua calon pengantin untuk melaksanakan ritual kelakat dalam proses perkawinan. Jika tidak dilaksanakan ada keyakinan salah satu dari keluarga calon pengantin akan mendapatkan musibah. Tujuan dilakukannya penelitian ini adalah untuk mengetahui pemahaman serta pandangan masyarakat terhadap tradisi kelakat dalam perkawinan bagi masyarakat muslim di Loloan Timur Jembrana Bali. Penelitian ini termasuk dalam penelitian kualitatif dengan pendekatan etnografi. Penelitian ini menggunakan metode pengumpulan data observasi, wawancara, dan dokumentasi. Adapun hasil dari penelitian ini adalah bahwasannya para tokoh agama dan tokoh masyarakat sekitar sependapat jika tradisi kelakat merupakan tradisi yang dapat membawa masyarakat pada kemusyrikan. Dalam pandangan syara dari segi keabsahannya, tradisi kelakat termasuk al-'urf al-fasid, yaitu dikarenakan tradisi ini menggunakan ritual meminta perlindungan dari para leluhur.
\end{abstract}

It is a belief among parents of bride or groom to practice kelakat ritual in marriage process. If they do not practice that kind of ritual, the family will get bad luck. The aim of this research is to know the understanding and perception of people towards this tradition among Muslim society in East Loloan, Jembrana Bali. This research is qualitative research with ethnography approach. It uses observation, interview and documentation technique of data collecting. The result of this research reveals that religious figures as well as social figures agree that practicing kelakat is prohibited due to its impact which will bring society into belief to more than one God. In term of Islamic Law, it s legality is part of al- urf al-fasid (bad tradition) because it uses asking guardianship from the ancestors ritual.

Kata Kunci; Tradisi Kelakat, Leluhur, Ritual

Masyarakat Indonesia memiliki tradisi dan keyakinan yang beragam terkait dengan pernikahan dan penghormatan terhadap leluhur. Salah satunya adalah ritual kelakat yang ada pada masyarakat Bali. Kelakat adalah mengundang leluhur atau nenek moyang bahwa kerabat mereka akan melaksanakan suatu pernikahan. Hal ini merupakan suatu bentuk penghormatan kepada nenek moyang mereka yang sudah mati ratusan tahun yang lalu, yang biasanya mereka menyebut dirinya memiliki hubungan kekerabatan dengan macan. Terdapat suatu kepercayaan pada sebagian orang tua para calon pengantin untuk melaksanakan ritual-ritual kelakat dalam proses perkawinan. Jika hal tersebut tidak dilaksanakan atau dilanggar, maka akan terjadi sesuatu yang tidak diinginkan pada salah satu keluarga calon pengantin, seperti kesurupan, sakit yang berkepan- 
jangan, masakan yang dimasak tidak bisa matang dan perabotan rumah tangga hilang pada waktu acara selamatan berlangsung. Dengan demikian, para keluarga calon pengantin akan sangat berhati-hati dalam melaksanakan suatu acara perkawinan karena hal ini akan menyebabkan kesulitan dan petaka bagi keluarga calon pengantin.[1]

Bagi masyarakat Kelurahan Loloan Timur Kecamatan Negara Kabupaten Jembrana Bali, terutama bagi mereka yang masih memegang teguh adat kepercayaan akan adanya tradisi dan mitosmitos dalam pelaksanaan suatu perkawinan, peranan kelakat sangat penting dan sulit untuk diabaikan. Hal ini disebabkan karena mereka menganggap bahwa kelakat merupakan salah satu cara untuk menghindarkan diri dari segala sesuatu yang tidak diinginkan dalam proses perkawinan yang akan mereka laksanakan.[2] Dalam pelaksanaan tradisi kelakat terdapat aciaci dan santun. Adapun isi dari aci-aci tersebut adalah nasi kuning, nasi putih dan nasi hitam, bubur katul, daun sirih, rokok, air putih (tempat yang harus digunakan adalah tekor/daun pisang yang dibentuk menyerupai mangkok), telur ayam kampung, bendera merah dan putih. Lalu aci-aci tersebut diletakkan di bagian rumah yang paling atas (pare-pare), sedangkan isi dari santun tersebut adalah beras, gula merah, pisang dan kelapa. lalu santun tersebut diletakkan di dapur umum dan di kamar pengantin. Sebagai pelengkap dari semua ini maka dibakarkan dupa Arab untuk memanggil roh para leluhur.[3]

Masyarakat Loloan Timur tidak semua melaksanakan tradisi kelakat dalam suatu acara baik sunatan maupun perkawinan. Tradisi $k e$ lakat ini secara khusus dilaksanakan oleh masyarakat muslim Loloan Timur yang masih memiliki kekerabatan dengan jelmaan macan

[1]Husin Abdul Jabar, Wawancara (Loloan Timur, 08 Februari 2007).

[2]Husin Abdul Jabar, Wawancara (Loloan Timur, 08 Februari 2007).

[3]Muyasarah, wawancara (Loloan Timur, 06 Februari 2007). atau sebagian masyarakat yang hanya ingin menghindari dari hal-hal yang tidak diinginkan dalam pelaksanaan perkawinan walaupun tidak memiliki hubungan kekerabatan dengan jelmaan macan tersebut.

\section{METODE}

Jenis penelitian ini adalah deskriptif kualitatif, penelitian kualitatif memberikan peluang untuk memahami fenomena menurut emic view atau pandangan aktor setempat. Di sini peneliti hanyalah orang yang belajar mengenai apa yang menjadi pandangannya, terutama terkait dengan tradisi $k e-$ lakat tentang perkawinan.[4]

Sedangkan pendekatan dalam penelitian ini menggunakan pendekatan etnografi yakni upaya memperhatikan makna tindakan dari kejadian yang menimpa orang yang ingin kita pahami. Beberapa makna ini terekspresikan secara langsung dalam bahasa dan banyak yang diterima dan disampaikan hanya secara tidak langsung melalui kata dan perbuatan.[5]

Dengan jenis dan pendekatan ini, peneliti melakukan observasi dengan terjun langsung mengamati proses pelaksanaan tradisi kelakat bagi masyarakat muslim Loloan Timur serta melakukan wawancara pada masyarakat desa setempat, sehingga dapat langsung mengalami sebagai bagian masyarakat dalam pelaksanaan tradisi kelakat itu sendiri. Disamping itu juga, peneliti berusaha melakukan interview dengan pelaku-pelaku tradisi kelakat sehingga akan mengetahui pemahaman, pemaknaan simbol dan pandangan masyarakat tentang tradisi ini.

\section{HASIL DAN PEMBAHASAN \\ Hasil}

Secara umum, adat dapat dipahami sebagai tradisi lokal (Local Custom) yang mengatur interaksi

[4]Nur Syam, Islam Pesisir (Yogyakarta: LKiS, 2005), 47.

[5]James P. Spradley, Metode Etnografi 
masyarakat. Dalam Ensiklopedi Islam disebutkan bahwa adat adalah mempunyai arti "kebiasaan" atau "tradisi" di masyarakat yang telah dilakukan berulang kali secara turun temurun. Kata "adat" di sini lazimnya dipakai dengan tanpa membedakan mana yang mempunyai sanksi, seperti "hukum adat" dan mana yang tidak mempunyai sanksi, seperti disebut adat saja [6]. Adapun yang dikehendaki dengan kata adat atau tradisi dalam karya ilmiah ini adalah adat yang tidak mempunyai sanksi, yaitu yang disebut adat saja.

Dalam literatur Islam, adat dapat disebut لعرف العادة العاد العang mempunyai arti adat atau kebiasaan. Menurut Abdul Wahâb Khalâf, 'urf adalah[7]:

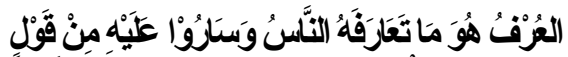

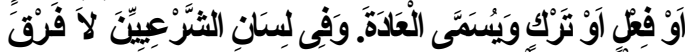

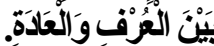

$$
\begin{aligned}
& \text { "Al-'urf adalah sesuatu } \\
& \text { yang telah diketahui oleh orang } \\
& \text { banyak dan dikerjakan oleh mere- } \\
& \text { ka, baik itu yang berupa perkataan, } \\
& \text { perbuatan ataupun sesuatu yang } \\
& \text { lazimnya untuk ditinggalkan. Hal } \\
& \text { ini dinamakan pula dengan al- } \\
& \text { 'adah. Sehingga dalam bahasa ahli } \\
& \text { syara' disana dijelaskan bahwa } \\
& \text { antara al-'urf dan al-'adah tidak } \\
& \text { terdapat perbedaan." }
\end{aligned}
$$

Menurut Al-Jurjaniy yang dikutip oleh Abdul Mudjib, al-'adah adalah[8]:

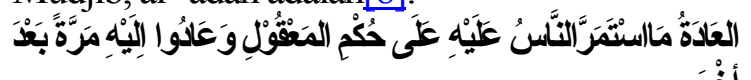

"Al-'Adah adalah sesuatu (perbuatan maupun perkataan) yang terus mene-

(Yogyakarta: PT. Tiara Wacana, 1997), 5.

[6]Ensiklopedi Islam, Jilid I (Cet.3; Jakarta: PT Ichtiar Baru Van Hoeve, 1999), 21.

[7]Abdul Wahâb Khalâf, Ilmu Ushûl al-Fiqih, (Cet. 12; tt: Al-Nash wal-Tauzik, 1978/1398), 89.

[8]Abdul Mudjib, Kaidah-kaidah Ilmu Fiqh (Cet.3; Jakarta: Kalam Mulia, 1999), 44. rus dilakukan oleh manusia, karena dapat diterima oleh akal dan manusia mengulang-ulanginya secara terus menerus."

Adapun terhadap al-'urf diartikan:

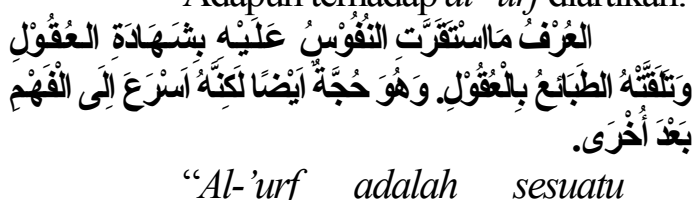

(perbuatan maupun perkataan) yang jiwa merasa tenang ketika mengerjakannya, karena sejalan dengan akal sehat dan diterima oleh tabi'at. Al-'urf juga merupakan hujjah bahkan lebih cepat untuk dipahami."

Memperhatikan definisidefinisi diatas, dan juga definisi yang diberikan oleh Ulama' yang lain, dapat dipahami bahwa al-'urf dan al-'adah adalah semakna yang dapat juga berupa perbuatan atau perkataan. Secara sederhana dapat dipahami bahwa adat; (a) Diketahui banyak orang atau harus memasyarakat; (b) Diamalkan secara terus menerus dan berulang kali.

Para ulama' ushul fiqh sepakat bahwa al-'urf al shâhih baik yang menyangkut al-'urf al-lafzhî, alurf al-'amali maupun menyangkut al-'urf al-'âm dan al-'urf al-khâsh dapat dijadikan hujjah dalam menetapkan hukum syara'. Menurut Imam alQarafi (ahli fiqh maliki) yang dikutip oleh Harun Nasroen menyatakan bahwa seorang mujtahid dalam menetapkan suatu hukum harus terlebih dahulu meneliti kebiasaan yang berlaku dalam masyarakat setempat, sehingga hukum yang ditetapkan tersebut tidak bertentangan atau menghilangkan kemaslahatan yang menyangkut masyarakat tersebut[9]. Dengan mengutip pendapat imam al-Syathibi (ahli ushul fiqh Maliki) dan ibnu Qayyim al-Jauziyah (ahli Fiqh Hanbali), Nasroen Harun juga menyatakan bahwa seluruh ulama' madzhab menerima

[9]Abdul Mudjib, Kaidah-kaidah, 142 
dan menjadikan 'urf sebagai dalil syara' dalam menetapkan hukum apabila tidak dijumpai dalam nash yang menjelaskan hukum masalah hukum yang sedang dihadapi. Misalnya, seseorang mempergunakan jasa pemandian umum dengan harga tertentu padahal lamanya ia di dalam kamar mandi dan berapa jumlah air yang terpakai adalah tidak jelas. Sesuai dengan ketentuan hukum syari'at Islam dalam suatu akad, kedua hal ini harus jelas akan tetapi perbuatan seperti itu telah berlaku luas dan menjadi kebiasaan di tengah-tengah masyarakat, sehingga seluruh ulama' madzhab menganggap syah akad ini. Alasan mereka adalah adat perbuatan yang berlaku.

Muhammad Abu Zahrah menyatakan bahwa adat ('urf) merupakan sumber hukum yang diambil oleh madzhab Hanafi dan Maliki[10]. Sesungguhnya perbedaan di antara para fuqaha' adalah adat (kebiasaan) dimana mereka itu berada.

Dari berbagai kasus adat yang dijumpai, para ulama' ushul fiqh merumuskan beberapa kaidah fiqh yang berkaitan dengan adat, di antaranya adalah.

\section{العادة محكمة مالم يخلف النص.}

Adat kebiasaan bisa dijadikan hukum selama tidak bertentangan dengan nash.

Adat bisa dijadikan sebagai salah satu dalil dalam menetapkan hukum syara' apabila telah memenuhi syarat-syarat sebagai berikut; (a) Berlaku secara umum, (b) Telah memasyarakat ketika persoalan yang akan ditetapkan hukumnya itu muncul, (c) Tidak bertentangan dengan yang diungkapkan secara jelas dalam suatu transaksi, (d) idak bertentangan dengan nash. [11]

Menurut al-Zarqa' yang dikutip oleh Nasrun

[10]Muhammad Abu Zahrah, "Ushl al-Fiqh” Terj. oleh Saifullah Ma'shum dkk (Cet.5; Jakarta:

Pustaka firdaus, 1999), 416.

[11]Nasrun Haroen, Ushul Fiqh I (Cet. 2; Jakarta: PT Logos Wacana Ilmu, 1997), 143-144.
Haroen, 'urf (adat kebiasaan) dibagi menjadi tiga macam[12]; Pertama, dari segi obyeknya ' urf (adat istiadat) dibagi pada al-'urf al-Lafdzhî (adat istiadat/ kebiasaan yang menyangkut ungkapan) dan al-'urf al-'amali (adat istiadat/ kebiasaan yang berbentuk perbuatan); (a) Al-'urf al-Lafdzî ( (لعرف اللفظىadalah adat atau kebiasaan masyarakat dalam mempergunakan ungkapan tertentu dalam meredaksikan sesuatu, sehingga makna ungkapan itulah yang dipahami dan terlintas dalam pikiran masyarakat, (b) Al-'urf al-'amali ( لعرف العملى)kebiasaan masyarakat yang berkaitan dengan perbuatan biasa atau muamalah keperdataan, yang dimaksud dengan "perbuatan biasa" adalah perbuatan masyarakat dalam masalah kehidupan mereka yang terkait dengan kepentingan orang lain.

Kedua, dari segi cakupannya, 'urf dibagi menjadi dua, yaitu al-'urf al- 'am (adat yang bersifat umum) dan al-'urf alKhâsh (adat yang bersifat khusus); (a) $A l$ adalah kebiasaan (العرف العام-'urf al-'am ( tertentu yang berlaku secara luas diseluruh masyarakat dan diseluruh (العرف الخاص)daerah, (b)Al-'urf al-Khâs ( adalah kebiasaan yang berlaku di daerah dan masyarakat tertentu.

Ketiga, dari segi keabsahannya dari pandangan syara', 'urf dibagi dua yaitu: al-'urf al-Shâhih (adat istiadat yang dianggap sah / kebenarannya) dan al-'urf al-fâsid (adat istiadat yang dianggap buruk / rusak); (a) Al-'urf asadalah kebiasaan (العرف الصحيح)Shâhih ( yang berlaku di tengah-tengah masyarakat yang tidak bertentangan dengan nash (ayat atau hadits), tidak menghilangkan kemashlahatan, dan tidak pula membawa mudharat kepada العرف الفاسداس (b)ereka, (b) Al-'urf al-Fâsid ( adalah kebiasaan yang bertentangan dengan dalil-dalil syara' dan kaidah-

kaidah dasar yang ada dalam syara'.

Adapun pengertian kepentingan umum adalah batasan 'urf (adat dan kebiasaan) adalah diartikan dengan sarana

[12]Nasrun Haroen, Ushul, 139-141. 
yang menyebabkan adanya kepentingan umum dan bisa dimanfaatkan secara umum. Sedangkan kepentingan umum dalam pandangan syari'at adalah sesuatu yang menjadi penyebab untuk sampai kepada maksud atau tujuan syara', baik berupa ibadah maupun adat.

Sedangkan kepentingan umum dalam pandangan syari'at Islam sangat penting, karena tujuan syara' adalah menciptakan terciptanya kepentingan umum dalam kehidupan manusia. Kepentingan umum yang dimaksud adalah bersifat dinamis dan fleksibel artinya pertimbangan kepentingan umum itu seiring dengan perkembangan zaman.

Jadi tujuan kepentingan umum dalam hukum Islam itu adalah prinsip dan ke-perinsip-an kepentingan umum sebagai tujuan hukum Islam ini telah disepakati oleh ahli-ahli hukum Islam. Secara umum kriteria kepentingan umum adalah pertama ialah memelihara kepentingan umum dengan kebajikan umum. Kepentingan umum itu dilakukan dengan dua usaha besar menolak kemudaratan yang menimpa manusia umumnya dan yang menimpa umat Islam khususnya dan mendatangkan kemanfaatan yang menghasilkan kebajikan umum bagi seluruh manusia pada umumnya dan bagi umat Islam pada khususnya. Oleh karena itu diantara dua tugas tersebut diletakkan suatu kaidah penolakan mudharat harus didahulukan atas mendatangkan manfaat. Kedua ialah mewujudkan kepentingan umum dengan bersandar kepada dua sendi akhlak, yaitu keadilan dan kebenaran.[13]

Selain merupakan sebuah tradisi, kelakat juga merupakan sebuah mitos yang masih diberlakukan oleh sebagian masyarakat muslim kelurahan loloan timur kabupaten jembrana bali. Kata mitos berasal dari bahasa Inggris " $m y t h$ " yang berarti dongeng atau cerita yang dibuat-

[13]Dahlan Tamrin, Filsafat Hukum Islam (Malang: UIN-Malang Press, 2007), 138-139. buat.[14] Sejarawan sering memakai istilah mitos untuk merujuk kepada cerita yang tak benar, yang dibedakan secara tegas dari cerita buatan mereka atau sejarah. Sedangkan menurut Malinowski mengklaim bahwa mitos adalah cerita yang mempunyai fungsi sosial tentang masa lampau yang berfungsi sebagai 'piagam' untuk masa kini sehingga dapat mempertahankan keberadaan pranata tersebut. [15] Agaknya akan semakin lebih jelas jika mitos bukan didefinisikan bukan dalam arti fungsinya melainkan dalam arti perulangan bentuknya atau 'rencana jahatnya' (arti istilah $m y$ thos dalam bahasa Yunani). Jung menyebutnya 'archetype' (pola dasar), sebagai produk yang tak pernah berubah dari ketidak sadaran kolektif.[16]

Sebagaimana para antropolog mengatakan bahwa keberadaan mitos seperti halnya tambal sulam, artinya cerita yang tidak bersambungan dirangkai satu demi satu tanpa hubungan jelas diantaranya. [17] Kasus sejarah tanpa arsip yang tentunya tidak ada dokumen-dokumen tertulis cuma tradisi lisan (dari mulut ke mulut), yang inilah kemudian oleh sebagian masyarakat kuno diklaim sebagai sejarah yang harus diyakini (mitos).[18]

Mitos adalah memberikan arah kepada kelakuan manusia dan merupakan semacam pedoman untuk kebijaksanaan manusia. Dengan mitos itu manusia dapat turut serta mengambil bagian dalam kejadian -kejadian sekitarnya, dapat menanggapi daya-daya kekuatan alam.[19]

Mitos adalah semacam takhayyul sebagai akibat

[14]John M. Echols dan Hasan Shadily, Kamus Inggris-Indonesia (Cet. XXIV; Jakarta: PT. Gramedia, 1993 ), 200.

[15]Peter Burke, Sejarah dan Teori Sosial (Jakarta: Yayasan Obor Indonesia, 2003), 152.

[16]Peter Burke, Sejarah, 154.

[17]Claude Levi-Streauss, Mitos dan Makna, Membongkar Kode-Kode Budaya (Yogyakarta: Marjin Kiri, 2005), 34.

[18]Claude Levi-Streauss, Mitos, 38.

[19]C.A. Van Peursen, Strategi Kebudayaan (Yogyakarta: Kanisius, 1988),

37. 
ketidaktahuan manusia, tetapi bawah sadarnya memberitahukan tentang adanya sesuatu kekuatan yang menguasai dirinya serta alam lingkungan. Kondisi bawah sadar inilah kemudian menimbulkan rekaan-rekaan dalam pikiran, yang lambat laun berubah menjadi kepercayaan. Biasanya dibarengi dengan rasa ketakjuban, ketakutan atau kedua-duanya, yang melahirkan sikap pemujaan (kultus). Sikap pemujaan yang demikian kemudian ada yang dilestarikan berupa upacara-upacara keagamaan (ritus) yang dilakukan secara periodik dalam waktu-waktu tertentu sebagian pula berupa tutur yang disampaikan dari mulut ke mulut sepanjang masa, turun-temurun dan yang kini dikenal sebagai cerita rakyat atau folklore. Biasanya dipakai menyampaikan asal-usul suatu kejadian istimewa yang tidak akan terlupakan. Demikianlah yang terjadi di masa-masa lampau, atau daerahdaerah terbelakang dengan alam pikiran manusia yang masih kuat di kuasai oleh kekolotan.[20] Ada dua tindakan yang ditampilkan dalam proses penyesuaian tindakan individu dengan nilai tradisi lama, yaitu penerimaan dan penolakan. Penerimaan terhadap nilai dalam tradisi lama biasanya berwujud dalam tindakan partisipatif dalam berbagai upacara adat yang dilakukan di berbagai ruang budaya. Banyaknya keterlibatan warga masyarakat dalam suatu upacara adat cukup membuktikan bahwa masyarakat menerima terhadap pelestarian tradisi lama.[21]

Namun demikian, ada juga sebagian warga masyarakat yang menolak pelestarian nilai dalam tradisi lama. Penolakan itu juga berbasis pada teks-teks suci berdasarkan cara pandang mereka. Penolakan tersebut berwujud bahasa dan tindakan. Selain itu juga berupa percobaan melanggar sebagai sarana untuk membuktikan bahwa kepercayaan-kepercayaan tersebut tidaklah benar adanya. Kepercayaan itu hanyalah mitos-mitos

[20]Soenarto Timoer, Mitos ura-Bhaya Cerita Rakyat Sebagai Sumber Penelitian Surabaya (Jakarta: Balai Pustaka, 1983), 11.

[21]Nur Syam, Islam, 252. yang dilestarikan.[22]

Pelaksanaan perkawinan biasanya tidak lepas dari kultur sosial masyarakat yang terkadang masih dilestarikan. Setiap daerah masih memiliki tradisitradisi adat perkawinan yang masih hidup. Pada umumnya pelaksanaan upacara perkawinan adat setempat berkaitan dengan susunan masyarakat atau kerabat yang masih dipertahankan oleh masyarakat bersangkutan dan bagaimanapun lembaga atau pranata pernikahan tetap diakui oleh hampir semua masyarakat Indonesia baik oleh agama, adat, suku dan lain sebagainya.[23]

Terkait dengan fenomena ini dalam kepercayaan adat perkawinan itu bukan hanya merupakan peristiwa penting bagi mereka yang masih hidup saja, tetapi perkawinan juga merupakan peristiwa yang sangat berarti serta yang sepenuhnya mendapat perhatian dan diikuti oleh arwah-arwah para leluhur kedua belah pihak. Dari arwah-arwah inilah kedua belah pihak beserta seluruh keluarganya mengharapkan restu bagi kedua mempelai. Oleh karena itu perkawinan mempunyai arti yang demikian penting sehingga pelaksanaannya senantiasa dimulai dan seterusnya disertai dengan upacara lengkap dengan sesajen.

\section{Pembahasan}

Mitos yang berkembang di Kelurahan Loloan Timur merupakan bentuk ungkapan dari masyarakat yang masih beranggapan bahwa sesuatu yang muncul dalam adat perkawinan mereka selama ini adalah hal yang harus diyakini, sehingga berakibat munculnya ketakutan dalam diri mereka dan berusaha untuk tetap berhati-hati terhadap adanya mitos tersebut. Dalam perkembangannya mitos yang muncul di kalangan masyarakat Loloan Timur seperti halnya tambal sulam, artinya cerita yang tidak bersambung dirangkai satu demi satu

[22]Nur Syam, Islam, 252.

[23]Hasan Shadily, Sosiologi untuk Masyarakat Indonesia, (Jakarta: Bina Aksara, 1985), 53. 
tanpa hubungan jelas diantaranya.

Berdasarkan pada pengalaman dan pemahaman sebagian masyarakat Loloan Timur tentang kejadian-kejadian pada zaman dahulu yang kemudian menjadi sejarah yang diceritakan dari mulut ke mulut, padahal mereka kurang begitu memahami tentang kejadian yang sebenarnya. Hal ini seperti yang terjadi pada sebagian masyarakat Loloan Timur yang hanya percaya begitu saja pada berita dari mulut ke mulut, mereka sendiri kurang selektif terhadap informasi itu, tidak heran kalau sebagian masyarakat Loloan Timur sangat meyakini tentang teradisi yang sudah menjadi warisan dari nenek moyang mereka dan suka pada apa yang disebut mitos.

Setiap acara perkawinan di Kelurahan Loloan Timur pada masyarakat tertentu akan selalu melaksanakan tradisi kelakat dengan tujuan untuk mengundang para leluhur atau meminta perlindungan kepada para leluhur agar upacara berjalan dengan lancar serta menghilangkan hal-hal yang dapat mencelakakan keluarga mereka. Dengan keadaan seperti ini menyadarkan mereka bahwa suatu tradisi atau mitos yang berasal dari nenek moyang (leluhur) mereka tidak boleh diabaikan, walaupun ada sebagian masyarakat yang secara tegas menolak adanya tradisi kelakat dalam perkawinan.

Pengertian adat dalam Islam, sebagaimana pendapat dari Al-Jurjânîy yang dikutip oleh Abdul Mudjib, al-'âdah ialah sesuatu (perbuatan maupun perkataan) yang terus menerus dilakukan oleh manusia, karena dapat diterima oleh akal dan manusia mengulang-ulanginya secara terus menerus. Dikonsepkan oleh Abdul Wahâb Khalâf, 'urf atau al-'adah adalah sesuatu yang telah diketahui oleh orang banyak dan dikerjakan oleh mereka, baik itu yang berupa perkataan, perbuatan ataupun sesuatu yang lazimnya untuk ditinggalkan. Jadi, tradisi kelakat merupakan suatu adat karena; (a) Diamalkan dan dipertahankan secara turun-temurun, berulang kali dilaksanakan secara terus menerus sebagai syarat urgen untuk bisa dikatakan sebagai adat, (b) Diketahui oleh seluruh masyarakat muslim Loloan Timur pada khususnya dan diketahui oleh seluruh masyarakat Bali pada umumnya.

Dari segi obyeknya, tradisi kelakat karena العرف العملى)termasuk al-'urf al-'amali ( tradisi ini dilakukan oleh masyarakat muslim dalam menghadapi siklus kehidupan. Sedangkan dari segi (لعرف الخاص), cakupannya termasuk al-'urf al-khâs ( karena tradisi kelakat merupakan kebiasaan yang dilakukan oleh kalangan masyarakat muslim Loloan Timur, artinya masyarakat yang ada di Negara Bali, sementara di daerah-daerah lainnya tidak melakukan tradisi kelakat ini.

Ada dua tindakan yang ditampilkan dalam proses penyesuaian tindakan individu dengan nilai tradisi lama, yaitu penerimaan dan penolakan. Penerimaan terhadap nilai dalam tradisi lama biasanya berwujud dalam tindakan partisipatif dalam berbagai upacara adat yang dilakukan di berbagai ruang budaya. Banyaknya keterlibatan warga masyarakat dalam suatu upacara adat cukup membuktikan bahwa masyarakat menerima terhadap pelestarian tradisi lama.

Namun demikian, ada juga sebagian warga masyarakat yang menolak pelestarian nilai dalam tradisi lama. Penolakan itu juga berbasis pada teksteks suci berdasarkan cara pandang mereka. Penolakan tersebut berwujud bahasa dan tindakan. Selain itu juga berupa percobaan melanggar sebagai sarana untuk membuktikan bahwa kepercayaan-kepercayaan tersebut tidaklah benar adanya. Kepercayaan itu hanyalah mitos-mitos yang dilestarikan.

Menurut masyarakat Kelurahan Loloan Timur, tradisi kelakat ini bukan hanya untuk mengundang roh para leluhur pada acara selamatan pernikahan yang disertai dengan aci-aci dan santun yang dipersembahkan kepada leluhur, tetapi ritual ini juga dianggap dapat memberi keselamatan dan kebahagiaan dalam acara selamatan. Dengan alasan itulah mereka tidak mengikuti tradisi kelakat tersebut karena tradisi tersebut merupakan praktek ritual yang mengarah kepada perbuatan syirik dan ritual tersebut disertai dengan hal-hal yang menyebabkan syirik kepada Allah.

Menurut KH. Fathurrahim selaku tokoh agama, dilihat dari tujuannya saja ia sudah tidak setuju, apalagi jika melakukannya. Beliau menyatakan tradisi kelakat tidak ada hubungannya dengan ajaran agama Islam, karena yang menentukan segala sesuatunya hanyalah Allah. Jadi jika perlu tradisi ini sebaiknya ditinggalkan, karena dapat menjerumus- 
kan kita kepada kesyirikan dan kekufuran.

Dari segi keabsahannya dari pandangan syara', tradisi kelakat termasuk al-'urf al-fâsid. Karena tradisi kelakat yang masih menggunakan ritual animistis, seperti meminta perlindungan dari arwah para leluhur. Karena dapat menyebabkan kemudaratan, yaitu timbulnya hal-hal yang berbau syirik, hal ini sangat bertentangan dengan nash (ayat dan hadist) dalam ajaran Islam. Mempercayai hal-hal seperti itu menurut Islam adalah syirik, sebagaimana firman Allah:[24]

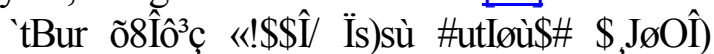
\$, Jİ̀ã ÇÍÑ்̀

“.....Barang siapa yang mempersekutukan Allah, maka sungguh ia telah berbuat dosa yang besar".

Selain itu, mempercayai adanya kekuatan dan pertolongan dari adanya tradisi kelakat adalah perbuatan yang tidak dapat mendatangkan kebaikan dan kemanfaatan, sebagaimana firman Allah:[25]

crßçc7:ètur `ïB Âcrß «!\$\# \$tB w öNèdÛØo wur óOßgãèxÿZt

"Dan mereka menyembah selain dari pada Allah apa yang tidak dapat mendatangkan kemudlaratan kepada mereka dan tidak (pula) kemanfaatan...."

Tradisi kelakat ini merupakan warisan dari masyarakat sebelumnya dan dilaksanakan secara turun temurun, akan tetapi dengan kemajuan zaman dan berkembangnya pengetahuan serta bertambahnya keyakinan masyarakat setempat, lambat laun tradisi kelakat ini mulai ditinggalkan karena dianggap tidak sesuai dengan pemahaman mereka dan lebih mengarah kepada kemudlaratan daripada kemaslahatan. Namun demikian, meskipun tradisi ini dapat mengarah kepada kesyirikan akan tetapi masyarakat yang melaksanakan tetap yakin kepada Allah dan pelaksanaan tradisi kelakat ini dimaksudkan untuk menghindari hal-hal negatif

[24] QS. an-Nisa' (4): 48.

[25]QS. Yunus (10): 18. yang dapat menghambat kelancaran suatu acara perkawinan.

\section{KESIMPULAN DAN SARAN}

\section{Kesimpulan}

Berdasarkan hasil penelitian yang telah peneliti lakukan tentang tradisi kelakat dalam perkawinan bagi masyarakat muslim Loloan Timur, maka dapat diambil kesimpulan yaitu; pertama, setiap acara perkawinan di Kelurahan Loloan Timur pada masyarakat tertentu akan selalu melaksanakan tradisi kelakat dengan tujuan untuk mengundang para leluhur atau meminta perlindungan agar acara perkawinan dapat berjalan dengan lancar serta menghilangkan hal-hal yang dapat mencelakakan keluarga mereka. Berdasarkan pemahaman masyarakat muslim Loloan Timur bahwa para roh leluhur yang telah mati akan selalu memberikan pangawasan kepada para penerusnya dan berharap untuk diundang dalam suatu acara perkawinan. Pemahaman tentang mitos di Loloan Timur merupakan salah satu faktor terjadinya tradisi kelakat dalam suatu acara perkawinan. Kedua, tradisi kelakat ini merupakan suatu adat yang di dalamnya terdapat kontroversial di antara kalangan masyarakat muslim Loloan Timur itu sendiri. Hal ini disebabkan oleh adanya keyakinan dan permohonan kepada roh para leluhur yang sudah mati untuk melindungi mereka yang melaksanakan tradisi kelakat. Sedangkan agama Islam sama sekali tidak pernah mengajarkan kepada umatnya untuk meminta perlindungan kepada selain Allah. Berdasarkan pandangan para tokoh agama maupun masyarakat, tradisi kelakat merupakan perbuatan yang dapat membuat kesyirikan, karena terdapat ritual permohonan kepada arwah leluhur untuk melindungi mereka yang melaksanakannya. Sedangkan dalam kajian 'urf, tradisi kelakat termasuk 'urf fasid dan tidak dapat dijadikan hukum, karena terdapat tujuan yang bertentangan dengan syari'at Islam, sehingga tradisi tersebut tidak boleh dilestarikan. Ketiga, tradisi kelakat merupakan salah satu bentuk ritual khusus yang dilaksanakan oleh sebagian masyarakat muslim Loloan Timur dalam rangka meminta perlindungan dan keselamatan 
kepada arwah para leluhur yang telah lebih dahulu meninggal dunia.

\section{Saran}

Dalam menyikapi adat kepercayaan lama di era modern ini, diharapkan bagi para mubaligh atau pemimpin Islam memberikan pemahaman terhadap praktek budaya yang dapat mengakibatkan terjadinya penyimpangan aqidah

\section{DAFTAR RUJUKAN}

Burke, Peter. 2003. Sejarah dan Teori Sosial. Jakarta: Yayasan Obor Indonesia.

Echols, John M. \& Hasan Shadily. 1993. Kamus Inggris-Indonesia. Cet. XXIV; Jakarta: PT. Gramedia.

Ensiklopedi Islam. 1999. Jilid I. Cet. 3; Jakarta: PT Ikhtiar Baru Van Hoeve.

Haroen, Nasrun. 1997. Ushul Fiqh I. Cet. 2; Jakarta: PT Logos Wacana Ilmu.

Khallaf, Abdul Wahab. 1978. Ilmu Ushul al-Fiqh. Cet. 12; tt: Al-Nash WalTauzik.

Levi-Streauss, Claude. 2005. mitoa dan Makna, Membongkar Kode-Kode Budaya. Yogyakarta: Marjin Kiri.

Mudjib, Abdul. 1999. Kaidah-Kaidah Ilmu Fiqh. Cet.3; Jakarta: Kalam Mulya. bagi umat muslim itu sendiri, sehingga masyarakat dapat memilih dan memilah mana yang baik dan mana yang dianggap kurang atau tidak baik.

Bagi masyarakat muslim Loloan Timur khususnya dalam kaitannya dengan pelaksanaan tradisi kelakat, hendaknya dapat lebih bijaksana dalam menyikapi tradisi kelakat ini, karena sikap ketidak hatihatian akan menyebabkan mereka terjerumus ke dalam lembah kesyirikan.

Peursen, C.A. Van. 1988. Strategi Kebudayaan. Yogyakarta: Kanisius.

Shadily, Hasan.1985. Sosiologi Untuk Masyarakat Indonesia. Jakarta: Bina Aksara.

Syam, Nur. 2005. Islam Pesisir. Yogyakarta: LKiS.

Tamrin, Dahlan. 2007. Filsafat Hukum Islam. Malang: UIN Malang Press.

Timoer, Soenarto. 1983. Mitos Qura-Bhaya Cerita Rakyat Sebagai Sumber Penelitian Surabaya. Jakarta: Balai Pustaka.

Zahrah, Muhammad Abu. 1999. Ushul alFiqh. Cet. 5. Terjemahan oleh Saifullah Ma`shum dkk. Jakarta: Pustaka Firadaus. 